\title{
Farklı dozlarda uygulanan selenyumun sorgum bitkisinde tane verimi ve yem kalitesi üzerine etkisi
}

\section{The effects of different selenium doses on sorghum grain yield and quality}

\author{
Dilara YILDIZ ${ }^{1}$, Mahmut KAPLAN ${ }^{1}$, Rıdvan TEMİGÜL ${ }^{2}$, Yusuf Murat KARDEŞ ${ }^{1}$ \\ ${ }^{1}$ Erciyes Üniversitesi, Ziraat Fakültesi Tarla Bitkileri Bölümü, Kayseri \\ ${ }^{2}$ Erciyes Üniversitesi, Fen Fakültesi Biyoloji Bölümü, Kayseri \\ Sorumlu yazar (Corresponding author): M. Kaplan, e-posta (e-mail): mahmutkaplan5@hotmail.com \\ Yazar(lar) e-posta (Author e-mail): ydilara22@hotmail.com, rtemizgul@erciyes.edu.tr, yusufmuratkardes@hotmail.com
}

\section{MAKALE BİLGİSİ}

Alınıș tarihi 13 Şubat 2018

Düzeltilme tarihi 11 Nisan 2018

Kabul tarihi 13 Nisan 2018

\section{Anahtar Kelimeler:}

Selenyum

Sorgum

Tane verimi

Morfolojik özellikler

Kalite

\begin{abstract}
ÖZ
Çalışmanın amacı; farklı selenyum form (selenat ve selenit) ve dozlarının $(0,2,4,8,16$ ve 32 $\mathrm{ppm}$ ) sorgum bitkisinin tane verim ve kalitesi üzerine etkisini araştırmaktır. Bu amaçla Acme broomcorn sorgum çeşidi kullanılmıştır. Kontrollü sera koşullarında saksılara $12 \mathrm{~kg}$ toprak konulmuştur. Tohumlar saksılara 3'er tekerrürlü olarak her bir saksıya 5'er adet atılmıştır. Daha sonra bitkiler seyreltilerek tek bir bitki bırakılmıștır. Selenyum suda çözündürülerek ekimle birlikte verilmiştir. Su tutma kapasitesine göre sulama yapılmış ve selenyumun yıkanması önlenmiştir. Dekara $20 \mathrm{~kg} \mathrm{~N}, 10 \mathrm{~kg} \mathrm{P}_{2} \mathrm{O}_{5}$ esas alınarak toprak ve miktarına göre hesaplanarak gübreleme yapılmıştır. Azotun yarısı ekimle, yarısı bitkiler 7-8 yapraklı olduğu dönemde uygulanmıştır. Hasat dönemine gelen bitkilerde bitki boyu, bitki çapı, salkım uzunluğu, tane verimi ile yaprak, salkım ve gövde oranları gibi morfolojik özellikler belirlenmiștir. Hasat edilen taneler ise $1 \mathrm{~mm}$ elek çapına ait değirmende öğütüldükten sonra kuru madde, ADF, NDF, ham protein, ham yağ ve ham kül özellikleri belirlenmiştir. Araștırma sonuçlarına göre, artan selenat ve selenit dozlarına bağlı olarak sorgumda bitki boyu, bitki çapı, salkım uzunluğu, tane verimi, yaprak ve salkım oranlarında azalmalar gözlemlenmiştir. Artan selenyum dozları ile tanede ham protein, ADF ve NDF oranlarında azalma olmuş, ham yağ oranında artış olmuş, kül oranında önce artış sonra azalma olmuştur.
\end{abstract}

\section{ARTICLE INFO}

Received 13 February 2018

Received in revised form 11 April 2018 Accepted 13 April 2018

Keywords:

Selenium

Sorghum

Grain yield

Morphological characteristics

Quality

\begin{abstract}
The present research was conducted to investigate the effects of different selenium forms (selenate and selenite) and doses ( $0,2,4,8,16$ and $32 \mathrm{ppm})$ on sorghum yield and quality. The sorghum variety of Acme broom corn was used as the plant material. Experiments were conducted under controlled greenhouse conditions. About $12 \mathrm{~kg}$ soil was placed into experimental pots. Seed were sown in tree replications as to have 5 seeds in each pot. Then, plants were thinned and a single plant left in each pot. Selenium was dissolved in water and applied to pots at sowing. Irrigations were performed based on field capacity to prevent selenium leaching. Fertilization was performed as to have $20 \mathrm{~kg} \mathrm{~N}$ and $10 \mathrm{~kg} \mathrm{P}_{2} \mathrm{O}_{5}$ per decare. Half of the nitrogen was applied at sowing and the remaining half was applied when the plants had 7-8 leaves. Plant heights, diameters, cluster lengths, grain yield, leaf-cluster-stem ratios were determined. Harvested grains were ground in a mill with $1 \mathrm{~mm}$ sieve. The ground samples were then subjected to dry matter, ADF, NDF, crude protein, crude oil and crude ash analyses. Current findings revealed that increasing selenite and selenate doses decreased plant height, diameter, cluster length, grain yield, leaf and cluster ratios. Increasing selenium doses also decreased grain protein content, ADF, NDF ratios and increased crude oil contents. Increasing doses initially increased then decreased crude ash ratios.
\end{abstract}

\section{Giriş}

Selenyum (Se) biriktiren bitkilere konsantratör bitkiler denir. Bu bitkiler fazla selenyumu topraktan alırlar ve daha sonra aldıkları bu selenyumu tekrar toprağa verirler. Bitkiler selenyumu organik ve mineral formda alır. Örneğin arpa, buğday, ayçiçeği hem organik hem de inorganik formda alabiliyorken bazı buğdaygiller sadece organik formda alabilirler. Bitkiler, selenyumun topraktan hayvanlara ve insanlara olan döngüsünde önemli bir rol oynamaktadır. Ana 
materyalin parçalanması sonucu selenyum toprağa geçer ve konsantratör bitkiler tarafindan kendi bünyelerine alınır. Hayvanlar da bu bitkiler aracılığı ile beslenerek alır. Hayvanlar aracılığı ile insanlara ulaşır (www.teknolojikarastirmalar.com). Sorgum, dünyada insan ve hayvan beslenmesinde en çok kullanılan beş ürün arasına girmiştir. Dünyada ekiliş ve üretim bakımından sıralamada buğday, mısır, çeltik ve arpadan sonra beşinci sırada yerini almıştır (Kumuk ve Avcıoğlu 1986). Sorgum kurağa, tuzluluğa dayanıklı ve düşük girdili tarımın hakim olduğu bölgelerde kolaylıkla yetişebilmektedir ( $\mathrm{Li}$ ve ark. 2010). Bu üstün özelliklerinden dolayı dünyanın birçok bölgesinde marjinal alanlarda hayvan beslemede yaygın bir şekilde kullanılmaktadır (Barile ve ark. 2007).

Besi hayvanlarında Se'un eksikliği birçok sorunlara neden olurken fazlalığ Selenyum eksikliğinde, büyümede gerileme, verim düşüklüğü ve ishal görülür. Genel olarak tüm hayvan türleri için tolere edilebilir Se miktarı NRC (30) tarafindan 2 ppm olarak verilmiştir (Ayaşan ve Baylan 2010). Koyunlarda fertilite ve döl verimi, koçlarda ise sperm sayısı yoğunluğu üzerine oldukça etkilidir. Eksikliğinde kalp ve iskelet kaslarında bozulma ve bunu takiben hareket bozuklukları, beyaz kas hastalığ kas hastalığı, üreme bozukluğu (reproductive disorder) kuzu ve buzağılarda kilo kaybı, verim düşüklügüne neden olmaktadır. Fazlalığında ise toksik etki yapmaktadır. Kılların dökülmesi, tırnak düşmesi, tembellik gibi belirtilerin ortaya çıkmasına neden olmuştur (Kocaarslan 2013). Beyaz kas hastalığı; selenyum ve $\mathrm{E}$ vitamini eksikliğinin neden olduğu çizgili kaslarda doku yıkımı şeklinde meydana gelmektedir. Bu hastalık kuzu, oğlak ve buzağıların önemli hastalıkları arasına girmektedir. Hastalık yürüyüş tutuklukları, kamburluk, adımlar kısa ve dik olarak kendini göstermektedir. Hareket halindeyken solunum güçlügü çekerler. İlerleyen dönemlerde hayvanlar ön ayaklarına dayanarak vücutlarının ön kısımlarını kaldırırken arka kısımlarını kaldıramayacak duruma gelmektedirler (Kocaarslan 2013).

Halilova (2004) yaptığı çalışmada; topraktaki Selenyum elementel selenyum, selenit, selenat, selenyum sülfit, selenyum sülfat ve selenyum siyanat şeklinde bulunduğunu belirtmiştir. Bitkilere yarayışlılığı üzerine $\mathrm{pH}$, kireçleme diğer elementlerin cins ve miktarı ve iklim koşulları etkili olmaktadır. Selenyumun yarayışlılığının alkali durumlarda daha fazla olduğu bildirilmiştir (Kacar ve Katkat 1998). Bitkilerin en kolay olarak alabildiği Se formu selenat olduğu bildirilmiştir. Ayrıca selenatın yüksek pH'ya sahip, iyi havalanabilen topraklarda daha çok olduğu bildirilmiştir.

$\mathrm{Bu}$ çalışmanın amacı farklı selenyum formlarının (selenat ve selenit) ve bu formların farklı dozlarının $(0,2,4,8,16$ ve 32 ppm) sorgum bitkisinde verim, verim parametleri ve tanenin yem özellikleri üzerine etkilerini incelemektedir.

\section{Materyal ve Yöntem}

Denemede Texas A\&M Üniversitesi'nden temin edilen Acme broom corn sorgum çeşidi materyal olarak kullanılmıştır. Denemede Selenyum kaynağı olarak konuya uygun oranlarda selenit $\left(\mathrm{SeO}_{3}\right)$ ve selenat $\left(\mathrm{SeO}_{4}\right)$ çözeltileri kullanılmıştır. $0.5 \mathrm{gr}$ toz halindeki selenit $\left(\mathrm{SeO}_{3}\right)$ ve selenat $\left(\mathrm{SeO}_{4}\right)$ alınıp $1000 \mathrm{ml}$ suda çözülerek $0.5 \mathrm{gr} \mathrm{l}^{-1}$ lik standart çözelti hazırlanmıştır. Deneme saksılara 3'er tekerrürlü olarak her bir saksıya 5'er tohum atılmıştır. Bitkilerin çıkışından sonra teke düşürülmüştür. Selanat $\left(\mathrm{SeO}_{4}\right)$ ve selenit $\left(\mathrm{SeO}_{3}\right)$ çözeltilerinden 5 farklı doz $(0$,
2, 4, 8, 16, 32 ppm) kullanılmıştır. Selanat ve selenit dozları suda çözündürülerek ekimle birlikte verilmiştir.

Ekim işlemi 21.04.2014 tarihinde Erciyes Üniversitesi Safiye Çırıkçığlu M.Y.O Uygulama serasında yapılmıştır. Kontrollü sera koşullarında saksılara $12 \mathrm{~kg}$ toprak saksi ${ }^{-1}$ tartılarak konulmuştur. Su tutma kapasitesine göre sulama yapılmış ve selenyumun yıkanması önlenmiştir. Dekara $20 \mathrm{~kg}$ $\mathrm{N}, 10 \mathrm{~kg} \mathrm{P}_{2} \mathrm{O}_{5}$ esas alınarak toprak ve miktarına göre hesaplanarak gübre uygulanmıştır. Azotun yarısı ekimle, yarısı bitkiler 7-8 yapraklı olduğu dönemde verilmiştir. Hastalık, zararlılar ve yabancı otlar için gerekli mücadeleler yapılmıştır. Bitkiler 25 Ekim 2014 tarihinde sert olum döneminde morfolojik özellikler alınmış ve elle hasat edilmiştir. Morfolojik özellik olarak bitki boyu, bitki çapı, gövde, yaprak ve salkım oranları, salkım uzunluğu ve tane verimi belirlenmiştir.

Hasat edilen sorgum tane örnekleri $1 \mathrm{~mm}$ 'lik elekleri olan değirmende öğütülerek kimyasal analizlere hazır hale getirilmiştir. Kuru madde, ham protein, ham yağ ve ham kül analizleri AOAC (1990)'da belirtilen yöntemlerle yapılmıştır. Hücre duvarını oluşturan NDF ve ADF gibi unsurların analizi sirasiyla Van Soest ve Wine (1967) ve Van Soest (1963)'de belirtilen yöntemle ANKOM 200 Fiber Analyzer (ANKOM Technology Corp. Fairport, NY, USA) cihazı kullanılarak yapılmıştır.

İncelenen karakterlere ait verilerin istatistiksel analizleri, tesadüf parselleri deneme desenine uygun olarak SAS istatistik paket programı kullanılarak yapılmıştır. Ortalama değerler arasındaki karşılaştırmalarda LSD testi kullanılmıştır (SAS 1999).

\section{Bulgular}

Sorgum bitkisine selenat ve selenit uygulamalarının verim ve verim özelliklerine ait değerler Çizelge 1'de verilmiştir. Sorgum bitkisine selenat ve selenit uygulamalarının tane verimi, salkım uzunluğu ve bitki çapı üzerine etkisi istatistiksel olarak $\% 5$ seviyesinde, bitki boyu, gövde ve salkım oranları üzerine etkisi istatistiksel olarak \% 1 seviyesinde önemli olmuştur. Selenat dozu artışı ile birlikte sorgumda tane veriminde, bitki boyunda, bitki çapında, salkım uzunluğunda ve salkım oranında azalma olurken, gövde oranında artış gözlemlenmiştir. Selenat uygulamasında tane verimi 14.82-21.90 $\mathrm{g} \mathrm{bitki}^{-1}$, bitki boyu $181.17-233.50 \mathrm{~cm}$, salkım uzunluğu $14.00-17.93 \mathrm{~cm}$, bitki çap1 9.74-11.71 mm, gövde oranı \% 46.76-\% 59.33 ve salkım oranı \% 29.58-\% 41.92 arasında değişim göstermiştir.

Sorgum bitkisine selenit uygulamalarından $32 \mathrm{ppm}$ uygulamasında bitki gelişimi olmadığı için gözlemler alınamamıştır. Selenit uygulaması ile $2 \mathrm{ppm}$ de verimde istatistiksel olarak önemsiz bir artış gözlemlenmiş ancak doz artışı ile tane veriminde azalmalar belirlenmiştir. Tane verimi 7.83-26.19 $\mathrm{g} \mathrm{bitki}^{-1}$ arasında değişmiştir. En düşük bitki boyu $204.50 \mathrm{~cm}$ ile $16 \mathrm{ppm}$ selenit uygulamasından elde edilirken, en yüksek bitki boyu $243.50 \mathrm{~cm}$ ile $2 \mathrm{ppm}$ selenit uygulamasından elde dilmiştir. Salkım uzunluğu 14.17-19.33 cm arasında değişmiş, en düşük değer 16 ppm selenit uygulamasından, en yüksek değer ise kontrol uygulamasından elde edilmiştir. En yüksek bitki çapı 2 ppm uygulamasından (12.49 mm), en düşük bitki çapı değeri ise 16 ppm uygulamasından $(10.47 \mathrm{~mm})$ elde edilmiştir. En yüksek gövde oranı $16 \mathrm{ppm}$ uygulamasından (\% 69.67), en yüksek yaprak oranı 4 ppm uygulamasından (\% 12.99) ve en yüksek salkım oranı kontrol uygulamasından (\% 38.60) elde edilmiştir. En düşük gövde oran1 \% 52.43 ile kontrol uygulamasından, en düşük yaprak oranı \% 8.97 ile 
kontrol uygulamasından ve en düşük salkım oranı ise \% 19.30 ile 16 ppm selenit uygulamasından elde edilmiştir.

Selenat ve selenit uygulaması yapılmış sorgum örneklerinin bazı kimyasal özelliklerine ait değerler Çizelge 2'de verilmiştir. Selenat dozu uygulamasının ham protein, ham kül ve ham yağ oranları üzerine etkisi istatistiksel olarak \% 5 seviyesinde, ADF ve NDF oranlarına etkisi ise istatistiksel olarak \%1 seviyesinde olmuştur. Selenat dozunun artışı ile ham protein oranı azalmış, en yüksek oran \% 9.91, en düşük \% 9.09 olmuştur. En yüksek ADF oran $1 \% 11.67$ ile 4 ppm uygulamasından elde edilmiş, 2 ppm uygulamasında istatistiksel olarak yanı grupta yer almıştır. En düşük $\mathrm{ADF}$ oranı ise \%9.80 ile kontrol uygulamasından elde edilmiştir. NDF oranı \% 20.51-23.87 arasında değişmiş, en yüksek değer kontrol uygulamasından elde edilirken, diğer tüm uygulamalar istatistiksel olarak aynı grupta yer almıştır. Ham kül içeriği yönünden 2 ppm (\% 3.33) ve 4 ppm (\% 3.36) selenat uygulamaları en yüksek grubu oluşturmuş, en düşük ham kül içeriği \% 2.09 ile kontrol parselinden elde edilmiş olmasına rağmen 8,16 ve $32 \mathrm{ppm}$ uygulamaları da istatistiksel olarak düşük grupta yer almıştır. En düşük ham yağ oranı \% 2.15 ile kontrol parselinden, en yüksek değer ise \% 2.68 ile 16 ppm selenat uygulamasından elde edilmiştir.

Selenit uygulamasında doz artışına bağlı olarak ham protein oranında azalmalar olmuş en yüksek ham protein oranı kontrol uygulamasından (\% 9.94), en düşük ise 16 ppm (\% 6.88) selenit uygulamasından olmuştur. En yüksek ADF içeriği \% 11.76 ile $4 \mathrm{ppm}$ uygulamasından elde edilmiş, en düşük $\mathrm{ADF}$ içeriği $\% 9.29$ ile 16 ppm uygulamasından elde edilmiştir. Kontrol, 2 ppm ve 8 ppm selenit uygulamaları da en düşük ADF içeriği grubuna dahil olmuşlardır. En yüksek NDF oranı \% 24.11 ile kontrol uygulamasından elde edilmiş, en düşük NDF oranı ise \% 18.69 ile 16 ppm selenit uygulamasından elde edilmiştir. En düşük ham kül içeriği $\% 2.50$ ile 16 ppm selenit uygulamasından, en yüksek ham kül içeriği ise \% 3.19 ile $4 \mathrm{ppm}$ selenit uygulamasından elde edilmiştir. En düşük ham yağ oranı \% 1.85 ile kontrol parselinden, en yüksek değer ise $\% 2.86$ ile $16 \mathrm{ppm}$ uygulamasından elde edilmiş, fakat tüm selenit uygulamaları istatistisel olarak en yüksek grupta yer almıştır.

Çizelge 1. Farklı dozlarda selenat ve slenit uygulanmış sorgumda verim ve verim özellikleri ait ortalama değerler.

Table 1. Mean values of yield and yield characteristics of different selenium forms and doses.

\begin{tabular}{|c|c|c|c|c|c|c|c|}
\hline \multirow{2}{*}{ Dozlar } & \multicolumn{7}{|c|}{ Selenat $\left(\mathrm{SeO}_{4}\right)$} \\
\hline & Verim & Bitki B & SalkımU & Bitki Ç & Gövde & Yaprak & Salkım \\
\hline Kontrol & $21.90 \mathrm{a}$ & $233.50 \mathrm{a}$ & $17.93 \mathrm{a}$ & $11.71 \mathrm{a}$ & $46.76 \mathrm{e}$ & 11.32 & $41.92 \mathrm{a}$ \\
\hline $2 \mathrm{ppm}$ & $20.11 b$ & $218.33 \mathrm{a}$ & $17.14 \mathrm{~b}$ & $11.61 \mathrm{a}$ & $49.37 \mathrm{~d}$ & 11.32 & $39.64 \mathrm{~b}$ \\
\hline $4 \mathrm{ppm}$ & $20.10 \mathrm{~b}$ & $216.00 \mathrm{~b}$ & $17.07 \mathrm{~b}$ & $11.51 \mathrm{~b}$ & $52.49 \mathrm{c}$ & 12.30 & $35.20 \mathrm{c}$ \\
\hline $8 \mathrm{ppm}$ & $18.59 \mathrm{~b}$ & $196.67 \mathrm{~b}$ & $15.83 \mathrm{~b}$ & $10.07 \mathrm{~b}$ & $53.40 \mathrm{c}$ & 12.33 & $34.27 \mathrm{~d}$ \\
\hline $16 \mathrm{ppm}$ & $15.61 \mathrm{c}$ & $193.00 \mathrm{c}$ & $15.00 \mathrm{c}$ & $9.83 \mathrm{c}$ & $55.58 \mathrm{~b}$ & 12.28 & $32.15 \mathrm{~d}$ \\
\hline $32 \mathrm{ppm}$ & $14.82 \mathrm{c}$ & $181.17 \mathrm{c}$ & $14.00 \mathrm{c}$ & $9.74 \mathrm{c}$ & $59.33 \mathrm{a}$ & 11.09 & $29.58 \mathrm{e}$ \\
\hline LSD & 1.6881 & 19.522 & 2.3711 & 1.4889 & 2.0732 & 1.4479 & 2.1639 \\
\hline Sig. Deg. & $*$ & $* *$ & $*$ & $*$ & $* *$ & NS & $* *$ \\
\hline \multirow{2}{*}{ Dozlar } & \multicolumn{7}{|c|}{ Selenit $\left(\mathrm{SeO}_{3}\right)$} \\
\hline & Verim & Bitki B & SalkımU & Bitki Ç & Gövde & Yaprak & Salkım \\
\hline Kontrol & $26.19 \mathrm{a}$ & $229.17 \mathrm{a}$ & $19.33 \mathrm{a}$ & $11.48 \mathrm{ab}$ & $52.43 \mathrm{~d}$ & $8.97 \mathrm{c}$ & $38.60 \mathrm{a}$ \\
\hline $2 \mathrm{ppm}$ & $26.37 \mathrm{a}$ & $243.50 \mathrm{a}$ & $18.83 \mathrm{a}$ & $12.49 \mathrm{a}$ & $55.59 \mathrm{c}$ & $11.94 \mathrm{~b}$ & $32.47 \mathrm{~b}$ \\
\hline 4 ppm & $15.02 \mathrm{~b}$ & $231.33 \mathrm{a}$ & $15.50 \mathrm{~b}$ & $11.27 \mathrm{ab}$ & $60.27 b$ & $12.99 \mathrm{a}$ & $26.73 \mathrm{c}$ \\
\hline $8 \mathrm{ppm}$ & $12.81 \mathrm{c}$ & $227.33 \mathrm{a}$ & $14.83 \mathrm{c}$ & $10.56 \mathrm{~b}$ & $61.68 \mathrm{~b}$ & $11.83 \mathrm{~b}$ & $26.48 \mathrm{c}$ \\
\hline $16 \mathrm{ppm}$ & $7.83 \mathrm{~d}$ & $204.50 \mathrm{~b}$ & $14.17 \mathrm{c}$ & $10.47 \mathrm{~b}$ & $69.67 \mathrm{a}$ & $11.04 \mathrm{~b}$ & $19.30 \mathrm{~d}$ \\
\hline $32 \mathrm{ppm}$ & - & - & - & - & - & - & - \\
\hline LSD & 1.5939 & 21.375 & 1.1743 & 1.3456 & 2.7934 & 1.671 & 2.3818 \\
\hline Sig. Deg. & $*$ & $*$ & $* *$ & $*$ & $* *$ & $* *$ & $* *$ \\
\hline
\end{tabular}

Çizelge 2. Farklı dozlarda selenat ve selenit uygulanmış sorgumda kimyasal özelliklere ait ortalama değerler

Table 2. Mean values of chemical composition of different selenium forms and doses

\begin{tabular}{|c|c|c|c|c|c|}
\hline \multirow{2}{*}{ Dozlar } & \multicolumn{5}{|c|}{ Selenat $\left(\mathrm{SeO}_{4}\right)$} \\
\hline & Protein & ADF & NDF & Kül & Yă \\
\hline Kontrol & $9.91 \mathrm{a}$ & $9.80 \mathrm{c}$ & $23.87 \mathrm{a}$ & $2.09 \mathrm{~b}$ & $2.15 \mathrm{c}$ \\
\hline $2 \mathrm{ppm}$ & $9.58 \mathrm{~b}$ & $11.62 \mathrm{a}$ & $22.27 b$ & $3.33 \mathrm{a}$ & $2.45 \mathrm{~b}$ \\
\hline 4 ppm & $9.44 \mathrm{~b}$ & $11.67 \mathrm{a}$ & $22.06 \mathrm{~b}$ & $3.36 \mathrm{a}$ & $2.34 \mathrm{~b}$ \\
\hline $8 \mathrm{ppm}$ & $9.27 \mathrm{~b}$ & $11.32 \mathrm{~b}$ & $22.03 \mathrm{~b}$ & $3.00 \mathrm{~b}$ & $2.41 \mathrm{~b}$ \\
\hline $16 \mathrm{ppm}$ & $9.11 \mathrm{~b}$ & $10.51 \mathrm{~b}$ & $21.60 \mathrm{~b}$ & $2.99 \mathrm{~b}$ & $2.68 \mathrm{a}$ \\
\hline $32 \mathrm{ppm}$ & $9.09 \mathrm{~b}$ & $10.26 \mathrm{c}$ & $20.51 \mathrm{~b}$ & $2.89 \mathrm{~b}$ & $2.56 \mathrm{~b}$ \\
\hline LSD & 0.7284 & 0.9143 & 1.8354 & 0.3152 & 0.401 \\
\hline Sig. Deg. & $*$ & $* *$ & $* *$ & $*$ & $*$ \\
\hline \multirow{2}{*}{ Dozlar } & \multicolumn{5}{|c|}{ Selenit $\left(\mathrm{SeO}_{3}\right)$} \\
\hline & Protein & ADF & NDF & Kül & Yă̆ \\
\hline Kontrol & $9.94 \mathrm{a}$ & $9.54 \mathrm{~b}$ & $24.11 \mathrm{a}$ & $2.66 \mathrm{~b}$ & $1.85 \mathrm{~b}$ \\
\hline $2 \mathrm{ppm}$ & $9.21 \mathrm{a}$ & $10.33 \mathrm{~b}$ & $23.33 \mathrm{a}$ & $2.79 \mathrm{~b}$ & $2.54 \mathrm{a}$ \\
\hline $4 \mathrm{ppm}$ & $7.81 \mathrm{~b}$ & $11.76 \mathrm{a}$ & $23.47 \mathrm{a}$ & $3.19 \mathrm{a}$ & $2.56 \mathrm{a}$ \\
\hline $8 \mathrm{ppm}$ & $6.93 \mathrm{c}$ & $10.39 \mathrm{~b}$ & $22.15 b$ & $2.83 \mathrm{~b}$ & $2.79 \mathrm{a}$ \\
\hline $16 \mathrm{ppm}$ & $6.88 \mathrm{c}$ & $9.29 \mathrm{~b}$ & $18.69 \mathrm{c}$ & $2.50 \mathrm{~b}$ & $2.86 \mathrm{a}$ \\
\hline $32 \mathrm{ppm}$ & - & & & & \\
\hline LSD & 0.7612 & 1.3159 & 0.9841 & 0.6177 & 0.4222 \\
\hline Ön. Der. & $* *$ & $*$ & $* *$ & $*$ & $* *$ \\
\hline
\end{tabular}




\section{Tartışma ve Sonuç}

$\mathrm{Bu}$ çalışmada farklı selenyum formlarının (selenat ve selenit) ve dozlarının $(0,2,4,8,16,32 \mathrm{ppm})$ sorgum bitkisinin morfolojik ve biyokimyasal özellikler üzerine etkisini belirlemek amaçlanmıştır. Çalışmamızda artan selenyum dozlarına bağlı olarak bitki boylarında, salkım uzunluğunda, yaprak oranında ve çapında azalmalar gözlenmiştir. Bunların sonucu olarak ta gelişme geriliğinden kaynaklı tane veriminde azalma gözlenmiştir. Selenyum ile ilgili çalışma yapan Yılmaz (2006) Hordeum vulgare L. bitkisinde, artan selenyum konsantrasyonlarıyla ters orantılı olarak bitki boylarının ve gelişiminin azaldığ 1 bildirmiştir. Ağır metalin çeşidine ve miktarına bağlı olarak ağır metallerin bitkilerde yaprak alanında küçülme, sararma ve nekrotik leke oluşumları da görülmektedir (Ayhan ve ark. 2006). Çalışmamızda sorgum bitkisinin yaprak oranındaki azalmanın selenyumun toksik etkisinden kaynaklanmış olabileceği düşünülmektedir. Kara (2016) tane verimiyle fizyolojik parametreler (fotosentez hizı, stoma iletkenliği vb.) arasında olumlu ilişkiler olduğunu bildirmektedir. Ağır metallerin bitkilerdeki stomaların kapanmasına neden olduğu bunun sonucu olarak ta fotosentez hızının etkilendiği bildirilmektedir (Ayhan ve ark. 2006). Çalışmamızda da artan selenyum dozuna bağlı olarak fotosentetik aktivitenin azaldığ olduğu düşünülmektedir.

Çalıştığımız denemede 16 ppm selenat ve selenit uygulamalarında bitki salkım oranı ve salkım uzunluğu miktarlarında yüksek dozdan dolayı azalma gözlenmiştir. Selenat uygulanan bitkilerde tane verimi artan doz miktariyla beraber ters orantıli olarak azalma görülmüştür. Selenit uygulamasında ise $4 \mathrm{ppm}$ uygulamasında düşüş gözlenmiştir. Yapılan bir çalışmada buğday bitkisine yapraklarından farklı dozlarda $\left(0.5,1.0,10\right.$ ve $\left.20 \mathrm{~g} \mathrm{Se} \mathrm{ha}^{-1}\right)$ selenyum uygulanmış ve araştırma sonucuna göre tane verimi üzerine herhangi bir değişim olmadığı görülmüştür (Karadağ 2013).

Selenat uygulanan bitkilerde doz miktarıyla beraber yaprak oranında artış görülmüş daha sonra 16 ppm uygulamasıyla birlikte düşüş gözlenmiștir. Djanaguiraman ve ark (2004), soya fasulyesi tohumlarına ekimden önce 5 ppm Se ve ekimden 45, 60, 75 gün sonra yapraktan $50 \mathrm{ppm}$ ve $100 \mathrm{ppm} \mathrm{Se}$ uyguladiklarında, soya yaprak sayısının ve yaprak alanının arttığını bildirmektedir (Djanaguiraman ve ark. 2004). Selenit uygulamasında da aynı şekilde artış gözlemlenmiş, fakat $8 \mathrm{ppm}$ dozuyla birlikte düşme meydana gelmiştir. $\mathrm{Bu}$ dozlardan sonraki azalışın sorgum bitkisi için toksik etkiye sahip olmasından kaynaklanabileceği düşülmektedir.

Selanat ve selenit uygulanan bitkilerde artan doz miktarıyla birlikte NDF oranında da azalma olmuş ancak selenit 4 ppm uygulamasında biraz yükselip tekrar düşüş gözlenmiştir. Hayvan besleme kullanılan yemlerde ADF ve NDF kalite ölçütlerinden birisi olarak kabul edilir ve bunların oranlarını düşük olması istenir (Caballero ve ark. 1995). Çünkü bu maddeler hazmı zorlaştırmakta bunun sonucu olarak ta kaliteyi düşürmektedir. Bitkiler bünyelerinde ki fazla metal iyonlarını metabolik aktivitelerinin çok az olduğu hücre duvarında biriktirirler. $\mathrm{Bu}$ durum artan ağır metal dozu hücre duvarı birleşenlerini oluşturan ADF ve NDF miktarının da olumsuz etkilemektedir (Verklaij ve Schat 1990). Yapılan birçok çalışma da farklı ağır metallerin hücre duvarlarında biriktiği bildirilmektedir (Wang ve ark. 2003). Sorgum tanesinde selenyum stresi ile ham protein ADF ve NDF oranlarının azalması ham yă̆ miktarının oransal olarak artığını düşündürmektedir. Selenyum uyguladığımız sorgum bitkisinde yağ oranları ise selenat uygulamasında en yüksek 16 ppm dozunda gözlenmiştir. Selenit uygulamasında ise artan doz oranlarımızla birlikte yağ oranlarını artış ve olumlu etki görülmüştür. Selenit ve selenat uygulamalarında $8 \mathrm{ppm}$ dozuna kadar ham kül oranında artış gözlenirken, 16 ppm uygulamasıyla birlikte tekrar düşme görülmüştür. Elde ettiğimiz bulgular Kaplan ve Kızılşimşek (2012); Akdeniz ve ark (2003) ve Gül ve ark (1999)'un elde ettikleri sonuçlar ile benzer olmuştur.

Selenyum uygulanan bitkilerde selenyum dozu arttıça protein miktarında azalmalar gözlenmiştir. Buğdayda (İkizce 96) sodyum selenat uygulanmış olan bütün gurupları önemli seviyede etkilenmiştir. Selenyumun bitkinin gelişimini ve protein sentezini olumsuz etkilediği tespit edilmiştir (Gökbulut, 2010). Oryza sativa L. bitkisinde yapılan araştırmalarda ise protein miktarında azalma meydana gelmiş ve bizim çalışmamızla aynı doğrultuda sonuçlar elde edilmiştir (Türkmen 2010). Sonuç olarak selenyumun protein içeriği üzerine olumsuz etkisi görülmüştür.

Araștırma sonuçlarına göre, artan selenat ve selenit dozlarına bağlı olarak sorgumda bitki boyu, bitki çapı, salkım uzunluğu, tane verimi, yaprak ve salkım oranlarında azalmalar gözlemlenmiştir. Artan selenyum dozları ile tanede ham protein, ADF ve NDF oranlarında azalma olmuş, ham yağ oranında artış olmuş, kül oranında önce artış sonra azalma olmuştur. Sorgum bitkisinin Se hassasiyetinin yüksek olduğu, Se bakımından zengin yerlerde tarımının uygun olmadığı sonucuna varılmıştır.

\section{Teşekkür}

Çalışmanın yapılmasında destek sağlayan Erciyes Üniversitesi Bilimsel Araştırma Projeleri Birimi'ne teşekkür ederiz (Proje no: FYL-2015-6133).

\section{Kaynaklar}

Akdeniz H, Karslı MA, Nursoy H, Y1lmaz İ (2003) Tane sorgum çeşitlerinin besin madde kompozisyonu ve sindirilebilir kuru madde veriminin belirlenmesi. Turk J Vet Anim Sci (27): 1349-1355.

AOAC (1990). Official Methods of Analysis. 15th ed. Association of Official Analytical Chemists, Washington, DC.US.

Ayaşan T, Baylan M (2010) Çiftlik hayvanlarının beslenmesinde organik selenyumun önemi. Süleyman Demirel Üniversitesi Ziraat Fakültesi Dergisi 6(1): 34-43.

Ayhan B, Ekmekçi Y, Tanyolaç D (2006) Bitkilerde ağır metal zararları ve korunma mekanizmaları. Anadolu Üniversitesi Bilim Ve Teknoloji Dergisi 7(1): 1-16.

Barile VL, Tripaldi C, Pizzoferrato L, Pacelli C, Palocci G, Allegrini S, Maschio M, Mattera M, Manzi P, Borghese A (2007) Effect of different diets on milk yield and quality of lactating buffaloes: maize versus sorghum silage. Italian Journal of Animal Science 6: $520-523$.

Caballero R, Goicoechea EL, Hernaiz PJ (1995) Forage yields and quality of common vetch and oat sown at varying seeding ratios and seeding rates of vetch. Field Crops Research 41 (2): 135-140.

Djanaguiraman M, Devi DD, Shanker AK, Sheeba, JA, Bangarusamy U (2004) Impact of selenium spray on monocarpic senescence of soybean (Glycine max L.). Journal of Food Agriculture and Environment 2: 44-47.

Gökbulut T (2010) Bazı buğday çeşitlerinde selenyum birikimi ve selenyum toksisitesinin antioksidan enzim aktivitesine etkisi. Yüksek Lisans Tezi, Erciyes Üniversitesi Fen Bilimleri Enstitüsü Biyoloji Anabilim Dalı, Kayseri. 
Gül İ, Akıncı C, Başbağ M (1999) Diyarbakır sulu koşullarında ikinci ürün olarak yetiştirilen tane sorgum çeşitlerinde verim ve verim unsurlarının incelenmesi. Türkiye 3. Tarla Bitkileri Kongresi, 15-18 Kasim, Adana. 1999.

Halilova H (2004). Mikroelementlerin (I, Zn, Co, Mn, Cu, Se) biyojeokimyası. İlke-Emek Yayınları, Ankara.

Kacar B, Katkat AV (1998) Bitki Besleme. Uludağ Üniversitesi Güçlendirme Vakfı Yayın No: 127. VPAS Yayınları: 3.

Kaplan M, Kızılşimşek M (2012) Farklı tane sorgum (Sorghum bicolor L.) hat ve çeşitlerinin besleme değerlerinin belirlenmesi. Erciyes Üniversitesi Fen Bilimleri Enstitüsü Dergisi 28(1): 11-14.

Kara R (2016) Evaluation of flag leaf physiological traits of triticale genotypes under eastern Mediterranean conditions. Turk J Field Crops 21(1): 67-78.

Karadağ F (2013) Farklı dozlarda selenyum uygulamalarının haşhaş (Papaver somniferum L.) yapraklarında antioksidan enzimler üzerine etkisi. Yüksek Lisans Tezi, Gaziosmanpaşa Üniversitesi Fen Bilimleri Enstitüsü Biyoloji Anabilim Dalı, Tokat.

Kocaarslan F (2013) Siğırlarda gebeliğin son döneminde uygulanan vitamin e ve selenyumun postpartum dönem sorunları üzerine etkisi. Yüksek Lisans Tezi, Adnan Menderes Üniversitesi Sağlık Bilimler Enstitüsü Doğum ve Jinekoloji Anabilim Dalı, Aydın.

Kumuk T, Avcıoğlu R (1986) Sorgum yetiştiriciliği ve hayvan beslemedeki yeri ve önemi. Ege Üniversitesi Ziraat Fakültesi Yayınları No:485. 28 s. Bornova-İzmir.

Li R, Zhang H, Zhou X, Guan Y, Yao F, Song G, Wang J, Zhang C (2010) Genetic diversity in Chinese sorghum landraces revealed by chloroplast simple sequence repeats, Genet Resour Crop Evol 57: $1-15$.
SAS InstituteInc. (1999). SAS/ETS User's Guide, Version9.0. Cary, NC, USA: SAS Institute, Inc.

Türkmen N (2010) Toprak özellikleri ile selenyum yarayışlılı̆̆ arasındaki ilişkiler ve sarımsağın selenyum ile zenginleştirilmesi. Dalı Doktora Tezi, Ankara Üniversitesi Fen Bilimleri Enstitüsü Toprak Bilimi ve Bitki Besleme Ana Bilim Dalı, Ankara.

Van Soest PJ (1963) The use of detergents in the analysis of fibre feeds. II. A rapid method for the determination of fibre and lignin. Journal of the Association of Official Analytical Chemists 46: 829-835.

Van Soest PJ, Wine RH (1967) The use of detergents in the analysis of fibrous feeds. IV. Determination of plant cell wall constituents. Journalof the Association of Official Analytical Chemists, 50, 50-55.

Verklaij JAC, Schat H (1990) In: Heavy Metal Tolerance in Plants: Evolutuonary Aspects, Ed:A.J. Shaw, pp:179-193, CRC Press, Boca Raton.

Wang WS, Shan XQ, Wen B Zhang SZ (2003). Relationship between the extractable metals from soils and metals takep up by maize roots and shoots. Chemosphere 53: 523-530.

Yılmaz S (2006). Selenyum uygulamalarının arpada (Hordeum vulgare L.) selenyum, kükürt ve azot alımına ve aminoasit içeriğine etkisi. Erciyes Üniversitesi Fen Bilimleri Enstitüsü Biyoloji Anabilim Dalı Yüksek Lisans. 